We thank Sister $S$ Mee for help in performing these studies, Professor $\mathbf{R}$ Brooks for supervising the cortisol assays, and the Research Endowments Committee of St Thomas's Hospital and the British Diabetic Association for financial help.

Requests for reprints should be addressed to $\mathrm{N} M$ Wilson.

\section{References}

1 Brown TM, Harvey AM. Spontaneous hypoglycemia in "smoke" drinkers. ҰAMA 1941;117:12-5.

${ }^{2}$ Freinkel N, Singer DA, Arky RA, Bleicher SJ, Anderson JB, Silbert CK. Alcohol hypoglycemia I. Carbohydrate metabolism of patients with clinical alcohol hypoglycemia and the experimental reproduction of the syndrome with pure ethanol. 7 Clin Invest 1963;42:1112-33.

${ }^{3}$ Freinkel N, Cohen AK, Arky RA, Foster AE. Alcohol hypoglycemia II. A postulated mechanism of action based on experiments with rat liver slices. F Clin Endocrinol Metab 1965 ;25:76-94.

${ }^{4}$ Searle GL, Shames D, Cavalieri PR, Bagdade JD, Porte DJ. Evaluation of ethanol hypoglycemia in man. Turnover studies with ${ }^{14} \mathrm{C}-6$-glucose. Metabolism $1974 ; 23: 1023-35$

${ }^{5}$ Leiber CS. Metabolism and metabolic actions of ethanol. In: Freinkel N, ed. The year in metabolism 1975-6. New York: Plenum Medical, 1977 317-42.

6 Abramson EA, Arky RA. Acute antilipolytic effects of ethyl alcohol and acetate in man. $\mathcal{F}$ Lab Clin Med 1968;72:105-17.

7 Arky RA, Freinkel N. Alcohol hypoglycemia III. Effects of ethanol on plasma, glucose, ketone and free fatty acids in "juvenile" diabetics: a model for "nonketotic diabetic acidosis ?" Arch Intern Med 1964; 114:501-7.

${ }^{8}$ Bagdade JD, Gale CC, Porte D Jr. Hormone fuel interrelationships during alcohol hypoglycemia in man. Proc Soc Exp Biol Med 1972;141:540-2.
9 Steele R, Wall JS, De Bodo RC, Altszuler N. Measurement of size and turnover rate of body glucose pool by the isotope dilution method. Am f Physiol 1956;187:15-24.

${ }^{10}$ Kreisberg RA, Crawford Owen W, Siegel AM. Ethanol-induced hyperlacticacidemia: inhibition of lactate utilization. F Clin Invest 1971;50: 166-74.

11 Lochner A, Wulff J, Madison LL. Ethanol-induced hypoglycemia I. The acute effects of glucose output and peripheral glucose utilization in fasted dogs. Metabolism 1967;16:1-18.

12 Joffe BI, Shires R, Seftel HL, Heding LG. Plasma insulin, C-peptide, and glucagon levels in acute-phase ethanol-induced hypoglycaemia. $\mathrm{Br} \mathrm{Med}$ f 1977 ;ii :67-8.

13 Ylikahri RH. Ethanol-induced hypoglycemia in thyroxine-treated rats. Metabolism 1970;19:518-28.

14 Leiber CS, Leevy CM, Stein SW, et al. Effect of ethanol on plasma free fatty acids in man. $\mathcal{F} \mathrm{Lab}$ Clin Med 1962;59:826-32.

15 Lundquist F, Tygstrup N, Winkler KK, Jensen KB. Glycerol metabolism in the human liver: inhibition by ethanol. Science $1965 ; 150: 616-7$.

${ }^{16}$ Priem HA, Shanley BC, Malan C. Effect of alcohol administration on plasma growth hormone response to insulin-induced hypoglycaemia. Metabolism 1976;25:379-403.

17 Blackard WG, Boylen CT, Hinson TC, Nelson NC. Effect of lipid and ketone infusions on insulin-induced growth hormone elevations in rhesus monkeys. Endocrinology 1969;85:1180-5.

18 Rees LH, Besser GM, Jeffcoate WJ, Gouldie DJ, Marks V. Alcoholinduced pseudo-Cushing's syndrome. Lancet $1977 ; \mathrm{i}: 726-8$.

19 Zierler KL, Rabinowitz DJ. Effects of very small concentrations of insulin on forearm metabolism. Persistence of its action on potassium and free fatty acids without its effect on glucose. $\mathcal{F}$ Clin Invest $1964 ; 43: 950-62$.

${ }^{20}$ Brown PM, Tompkins CV, Juul SA, Sönksen PH. Mechanism of action of insulin in diabetic patients : a dose-related effect on glucose production and utilisation. $\mathrm{Br} \mathrm{Med} \mathcal{F} 1978 ; \mathrm{i}: 1239-42$.

(Accepted 6 January 1981)

\title{
Biochemical tests for diagnosis of phaeochromocytoma: urinary versus plasma determinations
}

\author{
P F PLOUIN, J M DUCLOS, J MENARD， E COMOY，C BOHUON，J M ALEXANDRE
}

\begin{abstract}
Fifteen patients with hypertension due to phaeochromocytoma and 35 controls with essential hypertension were studied to assess the diagnostic value of urinary and plasma biochemical determinations in phaeochromocytoma.

In every case of phaeochromocytoma the urinary concentration of vanillylmandelate, metanephrines, or adrenaline plus noradrenaline was diagnostic of the disease irrespective of whether the patient was normotensive or hypertensive at the time. Plasma determinations of adrenaline and noradrenaline, however, gave falsely negative results on three occasions.
\end{abstract}

These findings suggest that urinary biochemical deter-

\footnotetext{
Hypertension Clinic and Department of Urology, Hôpital SaintJoseph, 75674 Paris Cedex 14

P F PLOUIN, MD, assistant in medicine

J M DUCLOS, MD, assistant in urology

J MENARD, MD, associate professor

Department of Clinical Biochemistry, Institut Gustave Roussy, 94800 Villejuif

E COMOY, PHD, assistant

C BOHUON, PHD, associate professor

Department of Pharmacology, Hôpital Broussais, 75014 Paris J M ALEXANDRE, MD, associate professor
}

minations-particularly of metanephrines-are more reliable than plasma catecholamine measurements as a test for phaeochromocytoma. The test is particularly useful in patients with intermittent hypertension."

\section{Introduction}

Diagnosing phaeochromocytoma is easy in patients with sustained hypertension: measurement of 24-hour excretion of vanillylmandelate, metanephrines, and catecholamines suffices to confirm or exclude the presence of the tumour. ${ }^{1}$ Diagnosis is harder to establish when hypertension is intermittent, however, since tumoral secretion of catecholamines may be absent during normotensive periods. To assess the diagnostic value of urinary and plasma determinations in phaeochromocytoma, we measured urinary concentrations of catecholamine metabolites and resting plasma concentrations of catecholamines in 15 patients with phaeochromocytoma, four of whom had intermittent hypertension.

\section{Methods}

In 15 hypertensive patients the diagnosis of phaeochromocytoma was based on biochemical tests and confirmed at operation. Thirtyfive other patients diagnosed by conventional methods as having essential hypertension were used as controls. No patient received any treatment for 15 days before testing. A 24-hour urine collection was assayed for vanillylmandelate, metanephrine, and adrenaline 
Plasma and urinary values in controls (patients with essential hypertension) and patients with phaeochromocytoma

\begin{tabular}{|c|c|c|c|c|c|c|c|c|c|c|}
\hline & & & & & \multirow{2}{*}{$\begin{array}{c}\text { Supine } \\
\text { blood } \\
\text { pressure* } \\
(\mathrm{mm} \mathrm{Hg})\end{array}$} & \multicolumn{2}{|c|}{ Plasma concentrations ( $\mathrm{nmol} / \mathrm{l})$} & \multicolumn{3}{|c|}{ Urinary concentrations $(\mathrm{mmol} / 24 \mathrm{~h})$} \\
\hline & & & & & & Adrenaline & Noradrenaline & Vanillylmandelate & Metanephrines & Adrenaline + noradrenaline \\
\hline \multicolumn{11}{|c|}{ Patients with essential hypertension $(n=35)$} \\
\hline $\begin{array}{l}\text { Mean } \pm 1 S D \\
\text { Range } \\
\cdots\end{array}$ & 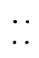 & $\because$ & $\because$ & $\therefore$ & $159 / 101+25 / 18$ & $\begin{array}{l}0.58+0.43 \\
0 \cdot 10-2 \cdot 03\end{array}$ & $\begin{array}{c}1.29 .0 .67 \\
0.24-3.35\end{array}$ & $\begin{array}{c:c}19 \cdot 60 & 5 \cdot 10 \\
7 \cdot 56-32 \cdot 30\end{array}$ & $\begin{array}{l}2.05: 0.87 \\
0.84-3.24\end{array}$ & $\begin{array}{c}0.40 \div 0.11 \\
0.30-0.64\end{array}$ \\
\hline \multicolumn{11}{|c|}{ Patients with phaeochromocytoma } \\
\hline \multicolumn{11}{|c|}{ Normotensive at time of sampling: } \\
\hline $\begin{array}{ll}1 & \ldots \\
2 & \cdots \\
3 & \cdots \\
4 & \cdots\end{array}$ & $\begin{array}{l}. \\
\cdots \\
\cdots\end{array}$ & $\begin{array}{l}. \\
\ldots \\
\ldots\end{array}$ & $\begin{array}{l}. . \\
\ldots \\
\ldots\end{array}$ & $\begin{array}{l}. \\
\cdots \\
\cdots\end{array}$ & $\begin{array}{r}93 / 62 \\
108 / 59 \\
124 / 60 \\
140 / 72\end{array}$ & $\begin{array}{l}0.87 \\
2.63 \\
1.29 \\
0.98\end{array}$ & $\begin{array}{r}1.49 \\
11.36 \\
1.42 \\
1.58\end{array}$ & $\begin{array}{l}30 \cdot 90 \\
27 \cdot 30 \\
43 \cdot 30 \\
50 \cdot 40\end{array}$ & $\begin{array}{r}7 \cdot 32 \\
53 \cdot 20 \\
4 \cdot 37 \\
19 \cdot 30\end{array}$ & $\begin{array}{l}0.85 \\
1.97 \\
1.74 \\
1.04\end{array}$ \\
\hline \multicolumn{11}{|c|}{ Hypertensive at time of sampling: } \\
\hline $\begin{aligned} 5 & \cdots \\
6 & \cdots \\
7 & \cdots \\
8 & \cdots \\
9 & \cdots \\
10 & \cdots \\
11 & \cdots \\
12 & \cdots \\
13 & \cdots \\
14 & \cdots \\
15 & \cdots\end{aligned}$ & $\begin{array}{l}. \\
\ldots \\
\ldots \\
\cdots \\
\cdots \\
\cdots \\
\ldots\end{array}$ & $\begin{array}{l}. \\
\ldots \\
\ldots \\
\ldots \\
\cdots \\
\cdots \\
\ldots\end{array}$ & $\begin{array}{l}. \\
\ldots \\
\cdots \\
\cdots \\
\cdots \\
\cdots \\
\cdots\end{array}$ & $\begin{array}{l}. . \\
\because \\
\because \\
\because \\
\because \\
\because \\
\because \\
\therefore \\
\end{array}$ & $\begin{array}{l}150 / 94 \\
153 / 95 \\
161 / 91 \\
156 / 96 \\
146 / 103 \\
17292 \\
180 / 109 \\
177 / 112 \\
155 / 131 \\
179 / 135 \\
180 / 135\end{array}$ & $\begin{array}{r}0.89 \\
3.01 \\
9.06 \\
13.49 \\
0.73 \\
2.00 \\
12.31 \\
2.12 \\
31.90 \\
2.63 \\
3.67\end{array}$ & $\begin{array}{r}3.63 \\
3.39 \\
95.51 \\
218.60 \\
21.21 \\
21.80 \\
9.77 \\
96.16 \\
66.60 \\
20.58 \\
83.32\end{array}$ & $\begin{array}{r}32 \cdot 30 \\
40 \cdot 30 \\
252 \cdot 00 \\
61 \cdot 00 \\
175.40 \\
143 \cdot 20 \\
223 \cdot 30 \\
88 \cdot 20 \\
100 \cdot 80 \\
65.50 \\
143.60\end{array}$ & $\begin{array}{r}5 \cdot 55 \\
20.60 \\
88.60 \\
65 \cdot 00 \\
16.50 \\
42 \cdot 60 \\
52 \cdot 70 \\
18.20 \\
43.80 \\
21 \cdot 70 \\
42 \cdot 80\end{array}$ & $\begin{array}{r}0.87 \\
1.05 \\
15.40 \\
13.00 \\
5.07 \\
5.22 \\
74.50 \\
6.67 \\
7.03 \\
3.09 \\
5.19\end{array}$ \\
\hline
\end{tabular}

* Mean of values obtained before and after blood sampling.

Conversion: SI to traditional units-Plasma adrenaline: $1 \mathrm{nmol} / 1 \approx 0 \cdot 18 \mathrm{ng} / \mathrm{ml}$. Plasma noradrenaline: $1 \mathrm{nmol} / 1 \approx 0 \cdot 17 \mathrm{ng} / \mathrm{ml}$. Urinary vanillylmandelate: $1 \mathrm{mmol} \approx$ $0 \cdot 198 \mathrm{mg}$. Urinary metanephrines: $1 \mathrm{mmol} \approx 0 \cdot 190 \mathrm{mg}$. Urinary adrenaline + noradrenaline: $1 \mathrm{mmol} \approx 0.169 \mathrm{mg}$.

plus noradrenaline concentrations. Normal values in our laboratory $( \pm 1 \mathrm{SD})$ are respectively $17 \cdot 6 \pm 5.5 \mathrm{mmol}(3.5 \pm 1 \cdot 1 \mathrm{mg}), 1.70 \pm$ $0.66 \mathrm{mmol}(0.32+0.13 \mathrm{mg})$, and $0.37 \pm 0.15 \mathrm{mmol}(0.06 \pm 0.03 \mathrm{mg}) /$ $24 \mathrm{~h}$. On the same day resting plasma adrenaline and noradrenaline concentrations were measured by radioenzyme assay. ${ }^{2}$ Blood samples were taken between 8 and 10 am through a microcatheter one hour after venepuncture and lying supine. Blood pressure was measured immediately before and after blood sampling and the two measurements averaged.

\section{Results}

Urinary metanephrine excretion in both normotensive and hypertensive patients with phaeochromocytoma was above the range for essential hypertension, and values for one or more of the three urinary metabolites were high in every case (table). In patients with phaeochromocytoma who were hypertensive at the time of sampling the plasma noradrenaline or adrenaline concentration, or both, was also high. Of the four normotensive patients (cases 1-4), one (case 2) had high resting plasma catecholamine values and the other three had values within the range for essential hypertension. In case 3 a symptomatic paroxysm occurred a few hours after measuring the resting plasma catecholamine concentration. At that time supine blood pressure was $148 / 116 \mathrm{~mm} \mathrm{Hg}$ and adrenaline and noradrenaline concentrations 7.25 and $4.71 \mathrm{nmol} / 1(1.33$ and $0.80 \mathrm{ng} / \mathrm{ml})$ respectively, above the range for essential hypertension (see table).

\section{Comment}

Our data confirm reports ${ }^{13}$ that urinary tests are a highly sensitive method for diagnosing phaeochromocytoma; urinary concentrations of catecholamine metabolites-particularly metanephrines-are high in over $95 \%$ of patients, the overlap with control values being negligible when specific methods are used. ${ }^{3}$ As regards plasma determinations, two distinct clinical settings must be considered: when hypertension is present, and presumably the tumour is actively secreting, plasma catecholamine values are high; their measurement is as useful as and more convenient than that of metanephrines in a 24-hour urine collection. On the other hand, when the patient is normotensive at the time of blood sampling plasma values may be falsely negative. ${ }^{4}$ Of our four normotensive patients, three had normal plasma adrenaline and noradrenaline concentrations, whereas their urinary concentrations of catecholamine metabolites were high enough to permit diagnosis. This dissociation of plasma and urinary values might be due to brief secretory paroxysms in any 24 -hour period in such patients, ${ }^{1}$ such as occurred in case 3 . In case 2 a high plasma noradrenaline concentration was found despite normal blood pressure, confirming the lack of correlation between blood pressure and plasma catecholamine values in phaeochromocytoma. ${ }^{4}$ As expected, this patient also had high urinary catecholamine metabolite values, like the normotensive patients with high plasma catecholamine concentrations observed by Bravo et al. ${ }^{5}$

Our results suggest that urinary measurements are more reliable for diagnosing phaeochromocytoma; there were no falsely negative results in our urine determinations but three occurred in our resting plasma measurements. Plasma sampling during paroxysmal attacks may be helpful, but values obtained by direct venepuncture of patients under stress should be interpreted with great caution.

\section{References}

${ }^{1}$ Engelman K. Phaeochromocytoma. Clinics in Endocrinology and Metabolism 1977;6:769-97.

2 Da Prada M, Zürcher G. Simultaneous radioenzymatic determination of plasma and tissue adrenaline, noradrenaline and dopamine within the femtomole range. Life $S c i$ 1976;19:1161-74.

${ }^{3}$ Gitlow SE, Mendlowitz M, Bertani LM. The biochemical techniques for detecting and establishing the presence of a pheochromocytoma. A review of ten years' experience. Am $\mathcal{F}$ Cardiol 1970;36:270-9.

${ }^{4}$ Manger WM. Plasma and tumor catecholamines and blood pressure in 38 patients with pheochromocytoma. In: Usdin E, Kopin IJ, Barchas J, eds. Catecholamines: basic and clinical frontiers. New York: Pergamon Press, 1979:1476-8.

5 Bravo EL, Tarazi RC, Gifford RW, Stewart BH. Circulating and urinary catecholamines in pheochromocytoma. Diagnostic and pathophysiological implications. N Engl F Med 1979;301:682-6.

(Accepted 18 December 1980)

ONE HUNDRED YEARS AGO The President of the Pharmaceutical Society of Liverpool, exhibited last week a sample of eugenol, which had been placed in his hands on the previous day. He said it had recently been noticed as a very energetic antiseptic, and it was also said to be a remedy for toothache. Both these properties could be readily understood, as oil of cloves, from which it was obtained, as well as oil of peppermint, had long been used to prevent ink, starch, paste, etc, from becoming mouldy. The oils had also been long regarded as remedies for toothache. It was also known as eugenic or caryophyllic acid, having a formula $\mathrm{C}_{10} \mathrm{H}_{12} \mathrm{O}_{21}$, and forming salts with bases. He said, it would be interesting to determine its rotatory power as compared with oil of cloves, which he would do before the next meeting. (British Medical fournal, 1881.) 